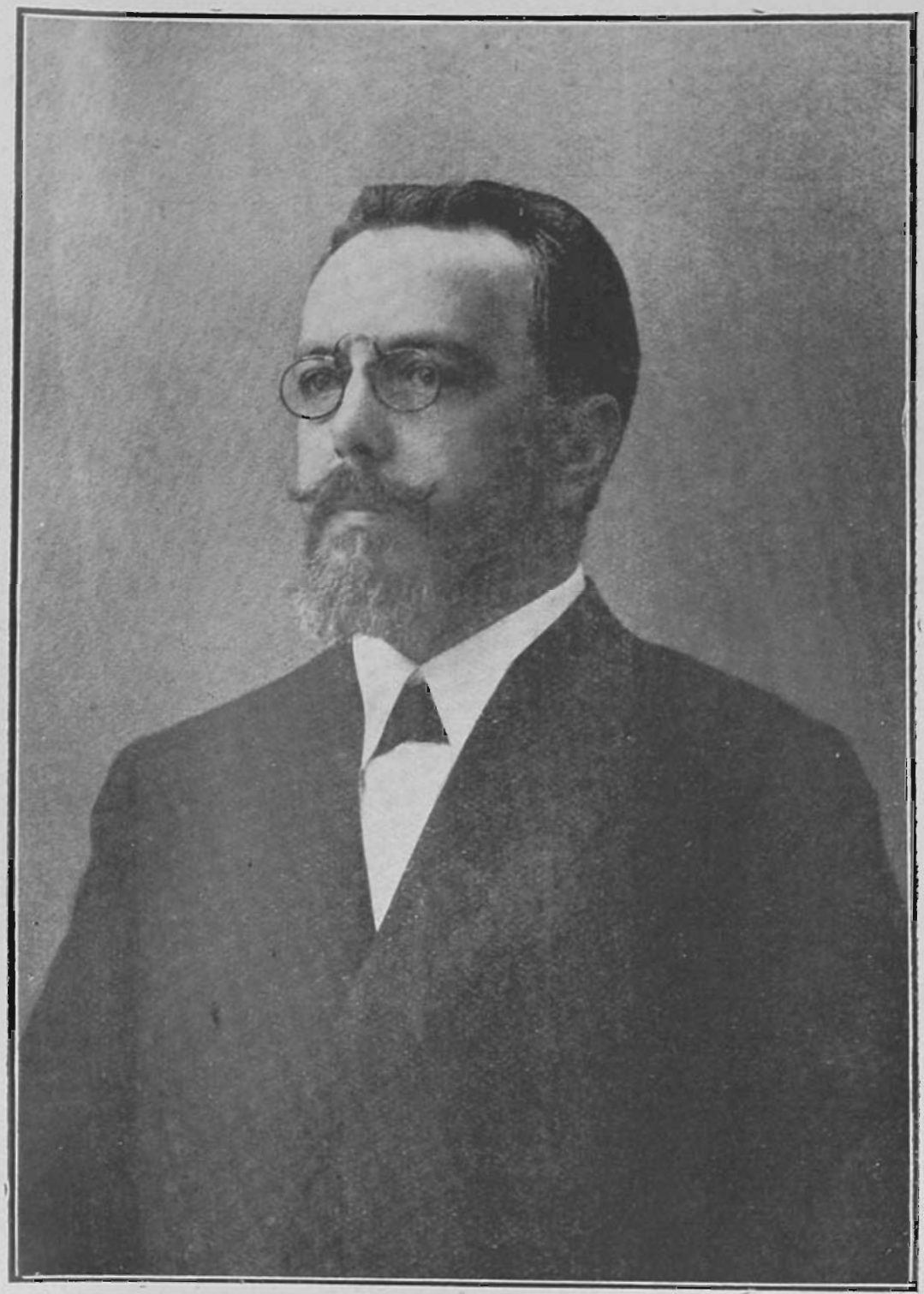

Dr. Gabriel de Rezende 


\section{DR. GABRIEL JOSÉ RODRIGUES DE REZENDE}

Nasceu em Campanha (Minas Geraes) em 22 de Julho de 1868. Falleceu em S. Paulo, aos 18 de Maio de 1923.

Era filho do Dr. Joaquim Leonel de Rezende Alvim, advogado no Sul de Minas e propagandista da Republica, e de D. Vitalina Novaes de Rezende.

Estudou as primeiras letras na Campanha; iniciou o curso de humanidades em Ouro Preto, e, afinal, fez os preparatorios em S. Paulo, matriculando-se em 1887 na Faculdade de Direito de. S. Paulo. Formou-se em Sciencias Juridicas e Sociaes no anno de 1891.

Em 1897 apresentou-se ao concurso de lente substituto de Direito Commercial, na Faculdade. Obteve o $1 .^{\circ}$ logar, sendo nomeado nesse mesmo anno. Em 1901, com o fallecimento do Dr. Brasilio Rodrigues dos Santos, foi nomeado lente cathedratico da referida cadeira, que regeu ininterruptamente.

Em 14 de Março de 1909, foi eleito para uma cadeira do Senado Estadual, tendo sido sempre reeleito nos periodos de 1910 a 1922.

Publicou, apenas, o "Curso de Fallencias" - resumo das suas preleç̧ões na Faculdade (1912).

A doença traiçoeira impediu -que reeditasse, augmentado e melhorado, esse seu trabalho e que finalizasse o "Curso de Direito Commercial" - dos quaes a familia conserva uns dez capitulos.

Publiçou, ainda, em 1913, os "Discursos", proferidos no Senado e no Congresso Constituinte. 
Existem delle na "Revista da Faculdade" e em revistas juridicas alguns pareceres e trabalhos esparsos, quasi todos attinentes á materia commencial.

Deixou viuva D. Maria Constança Benevides de Rezende.

Teve os seguintes filhos: Dr. Gabriel de Rezende Filho, casado.com D. Marina Penteado de Rezende, já fallecida; D. Maria Constança de Rezende Junqueira, casada com o Sr. Aurelio de Andrade Junqueira, commissario de café e capitalista; Dr. Leonel Benevides de Rezende, fanzendeiro, casado com D. Elza Sampaio Vidal de Rezende; D. Marina de Rezende do Amaral, casada com o Dr. Luiz Fernando do Amaral, engenheiro; D. Lavinia Benevides de Rezende, professora do Jardim da Infancia da Capital; José Ignacio Benevides de Rezende, estudante da Faculdade de Direito; Paula, Ignez, Francisca e Clotilde Benevides de Rezende.

O Dr. Gabriel de Rezende, pela sua extrema bondade e trato ameno, era muitissimo estimado na Faculdade. As suas prelecções eram ouvidas com prazer e proveito pelos alumnos que o idolatravam.

De uma familia de lentes, o seu filho Gabriel de Rezende Filho, digno successor, é hoje Livre-Docente da nossa Faculdade. 